\title{
REMOTE SENSING AND GIS TO SUPPORT COASTAL EROSION RISK ANALYSIS IN CALABRIA, ITALY
}

\author{
GIANDOMENICO FOTI, GIUSEPPINA CHIARA BARILLÀ, \\ GIUSEPPE BARBARO \& PIERFABRIZIO PUNTORIERI \\ DICEAM Department, Mediterranea University of Reggio Calabria, Italy
}

\begin{abstract}
In territories such as Calabria, Italy, characterized by about $750 \mathrm{~km}$ of coasts, the analysis of the coastal erosion risk is of increasing interest due to the considerable anthropic pressure observed in the last few decades. Index-based methods can be used to assess the risk of coastal erosion. The paper shows an analysis of the coastal erosion risk carried out in Calabria. The analysis was carried out in over 50 sample coastal areas, three of them were chosen as case studies for a detailed analysis. The analysis of the shoreline changes was carried out through the comparison of various cartography data, which consists of historical shorelines taken from the Open Data section of the Calabrian Geoportal, orthophotos taken from the Open Data section of the Italian Geoportal, and satellite imagery provided by Google Earth. The analysis was divided into four phases as follows. The first phase concerned the manual digitization of each missing shoreline, using QGIS for each orthophotos and using the spatial analysis tools of Google Earth Pro for each satellite imagery. The second phase concerned the evaluation of the beach width for each transept. Finally, the last phase concerned the determination of shoreline rates of change using end point rate (EPR) and net shoreline movement (NSM) statistics. Also, an index representative of the trend of erosion or advance of the coast was estimated. Finally, the methodology described in this paper is of particular relevance and interest in the planning and management of coastal areas. It allows us to quickly analyze cartographic data from different sources, using free software. Also, it is of general validity and is useful as a basis for the index-based coastal risk assessment methodology.
\end{abstract}

Keywords: remote sensing, shoreline changes, coastal erosion, coastal risk assessment, index-based methodology, GIS.

\section{INTRODUCTION}

The coastal erosion phenomenon is the result of a series of natural or induced processes which alter the sedimentary regime and modify the coastal morphology, causing a loss of surface of the emerged territory [1], [2].

Knowledge of coastal dynamics and of the factors that influence it, such as wave climate [3] and longshore [4], [5] and river transport [6], [7], is necessary for proper management and protection of coastal areas [8].

Coastal dynamics processes are strongly influenced by natural phenomena and anthropic interventions [9]-[11] which can affect both river basins, for example the construction of reservoirs, the sediment withdrawal, the reforestation, the hydraulic-forestry arrangements, the subsidence of lowland areas for pumping [12], [13], and coastal areas, for example the construction of port and coastal defense works [14]-[16].

Anthropogenic pressure can increase the vulnerability of the territory under the action of natural events such as floods and sea storms [17]-[19], especially in case of concurrent events [20], [21]. Furthermore, the effects of climate change can contribute to erosive phenomena, in terms both of sea level rise and of frequency and intensity of extreme weather events.

Therefore, in recent years there has been a widespread and growing interest in the coastal risk assessment methodologies [22]-[26], necessary to properly manage the risk areas by allocating the funds intended for coastal protection with a certain order of priority [27], [28]. 
With regard to the coastal risk assessment, the Italian and international panorama is characterized not only by different evaluation methodologies, variables between the different coastal regions, but above all by a great variety and dispersion of factors taken into consideration by these different methodologies [29]-[32]. Among the existing methods [33], the index-based methods are the simplest and most widely used. They are based on a quantitative or semi-quantitative evaluation of different variables or indicators which are combined with each other, through an appropriate set of weights, obtaining as a final result an overall index, the coastal vulnerability index (CVI) [34], [35]. In addition, these methods can be supported by GIS applications, therefore it is possible to produce maps that allow to describe the spatial distribution of the CVI index and to overlap these results with additional spatial information [36].

One of the most used coastal vulnerability indices is the one that identifies the evolutionary trend of the coast: this index, in fact, is very important because it allows to identify the state of a coast and to assess its vulnerability [37]. The identification of the shoreline and its changes allows to determine the advance or erosion rate in a given time period. Consequently, this index can be important for the evaluation of coastal erosion risk.

Recent advances in remote sensing and geographical information system (GIS) techniques allow us to estimate with great precision the shoreline position [38] and the shoreline changes over the years [39]-[44], and it should be noted that the use of any particular method of analysis being influenced by the data sources and the resources available [45]-[47].

In territories such as Calabria (Italy), characterized by about $750 \mathrm{~km}$ of coasts, the analysis of the coastal erosion risk is of increasing interest due to both the considerable anthropic pressure and the coastal erosion phenomena observed in the last decades [48].

The paper describes an analysis of the coastal erosion risk carried out in Calabria. In detail, over 50 sample coastal areas were analyzed through the comparison of various cartography data of the open data sections of Calabrian and Italian Geoportals, and of satellite imagery provided by Google Earth. This analysis allows to identify a methodology for estimating an index representative of the trend of erosion or advance of the coast. The following sections describe the study area, the methodology and the results.

\section{SITE DESCRIPTION}

Calabria is a region of southern Italy. From a morphological point of view, is mainly characterized by hills and mountains, with a percentage of less than $10 \%$ of plains. Also, Calabria has a narrow and elongated conformation, with a considerable coastal extension, exceeding $700 \mathrm{~km}$, and an alternation of beaches, mainly sandy and pebbly, and high coasts. The anthropogenic pressure is high, with the presence of numerous tourist activities and bathing establishments which make the coastal areas of fundamental importance in the regional economy. Calabria is bathed by two seas, Tyrrhenian and Ionian, by the Strait of Messina and by the Gulf of Taranto, each of them with different climatic characteristics and different fetches extensions. These differences lead to a remarkable variability of meteorological conditions between the different areas of Calabria.

The general analysis described in the paper concerns over 50 Calabrian towns (Fig. 1) and three of them were chosen as case studies for a detailed analysis. These towns are subject to significant erosive processes. Therefore, they are of significant interest for the coastal risk assessment. The three towns are Badolato, Melito Porto Salvo and San Lucido. Badolato is located on the Ionian coast and the construction of a harbor has triggered erosions of the order of a hundred meters (Fig. 2). Melito Porto Salvo is located at the southern end of Calabria, on the Ionian coast near the Strait of Messina, and some parts of the beach near the promenade and near the railway station have been totally eroded (Fig. 3). Finally, San Lucido is located 
on the Tyrrhenian coast and numerous coastal structures, consisting of T-groins, have been built to mitigate the significant erosion (Fig. 4).

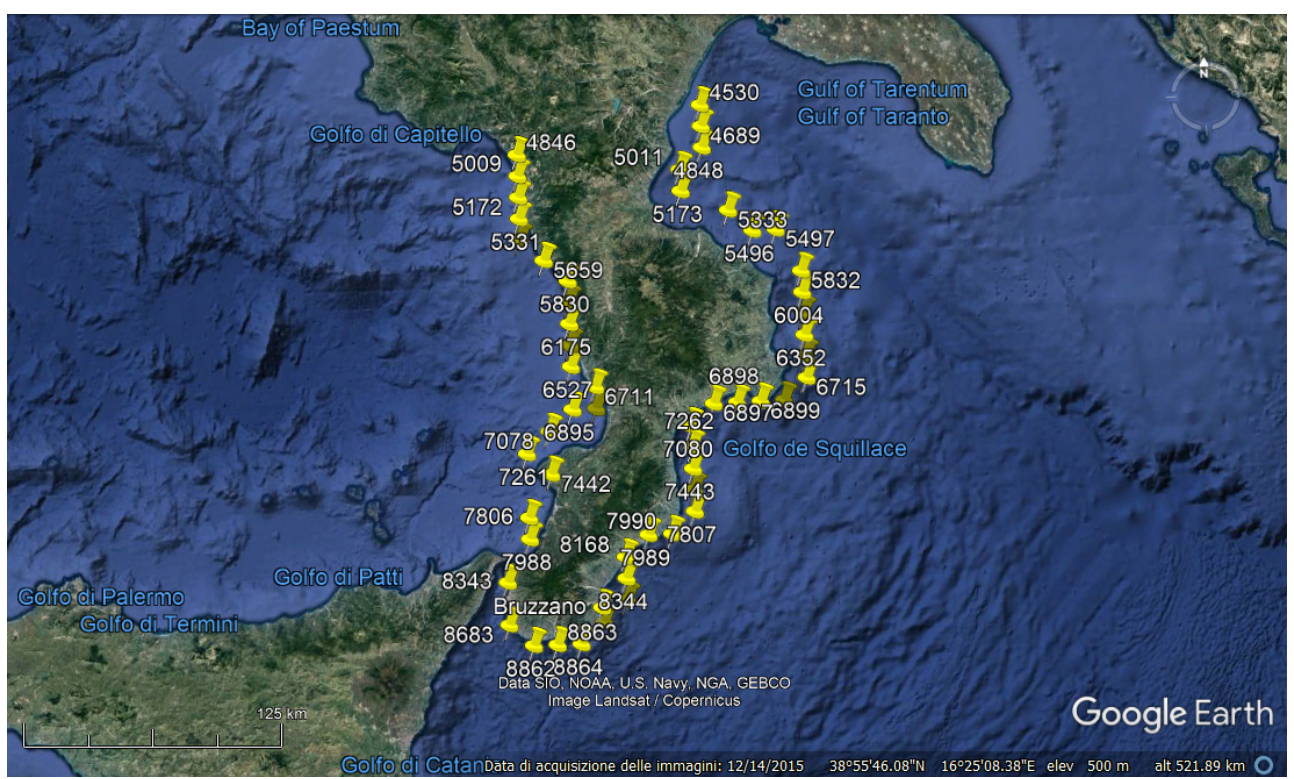

Figure 1: Calabrian towns examined, identified with a numerical code.

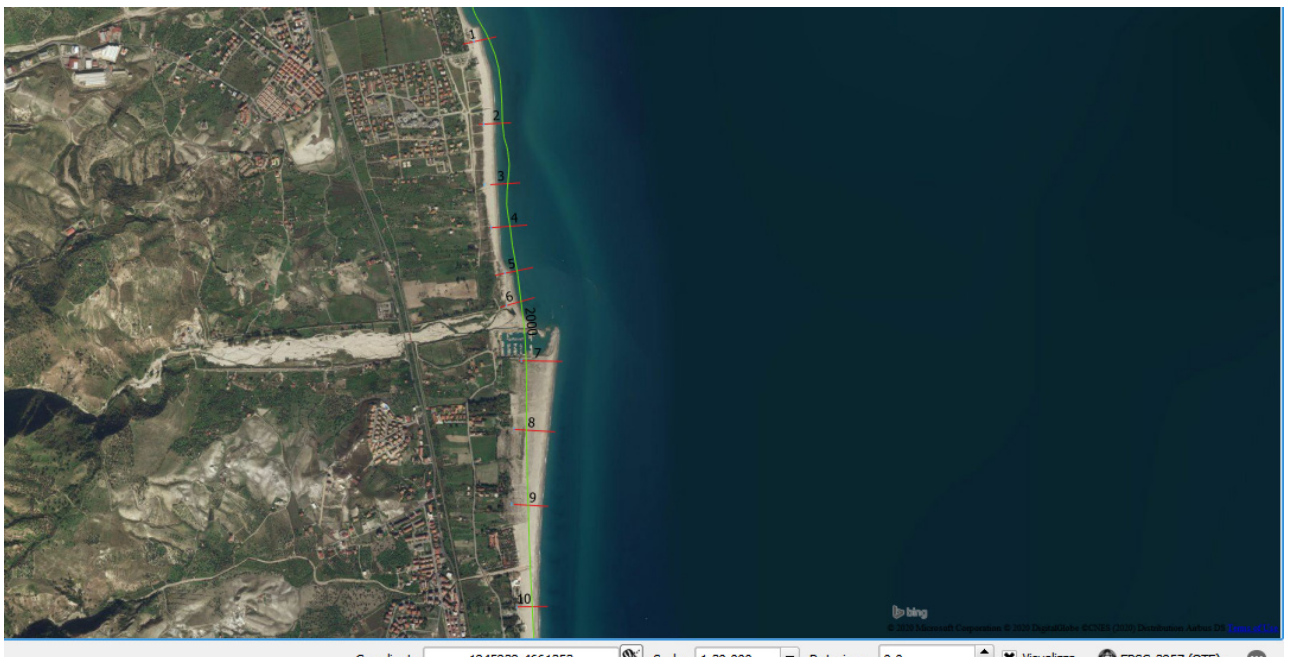

Figure 2: $\quad$ View from QGIS of Badolato. Red = Transepts; Green $=$ Shoreline of 2000, before the construction of the harbour. 


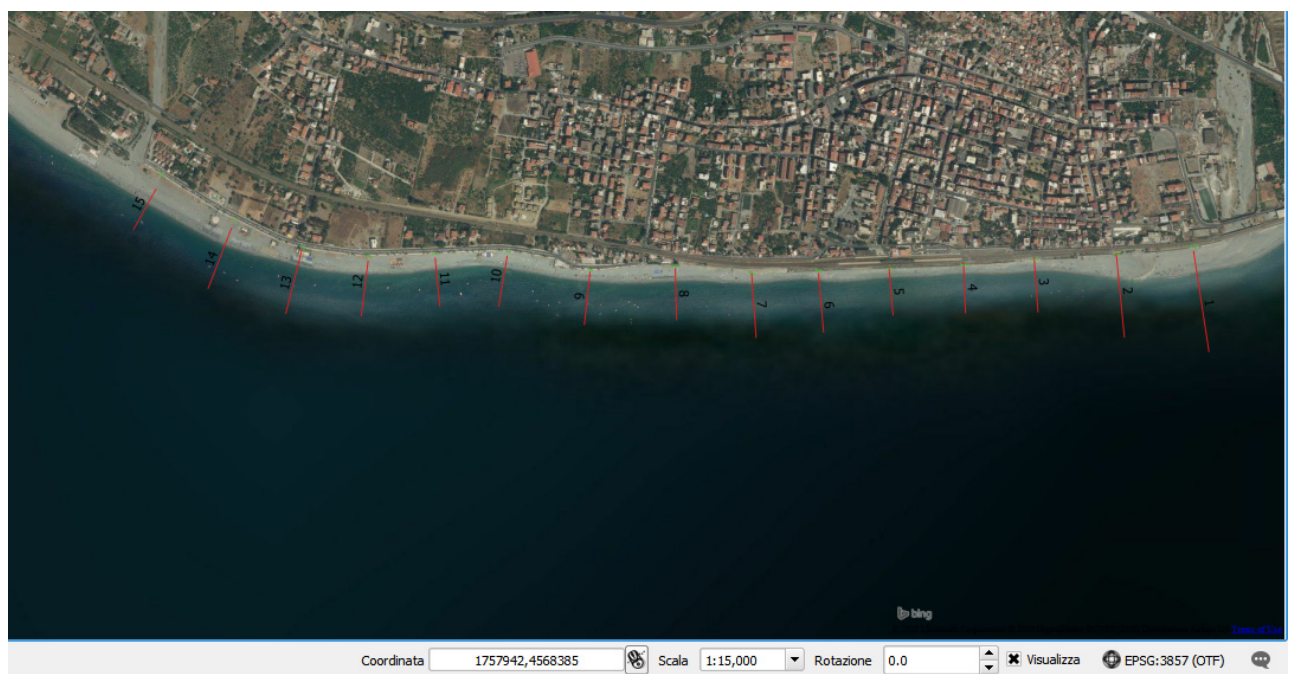

Figure 3: View from QGIS of Melito Porto Salvo. Red = Transepts.

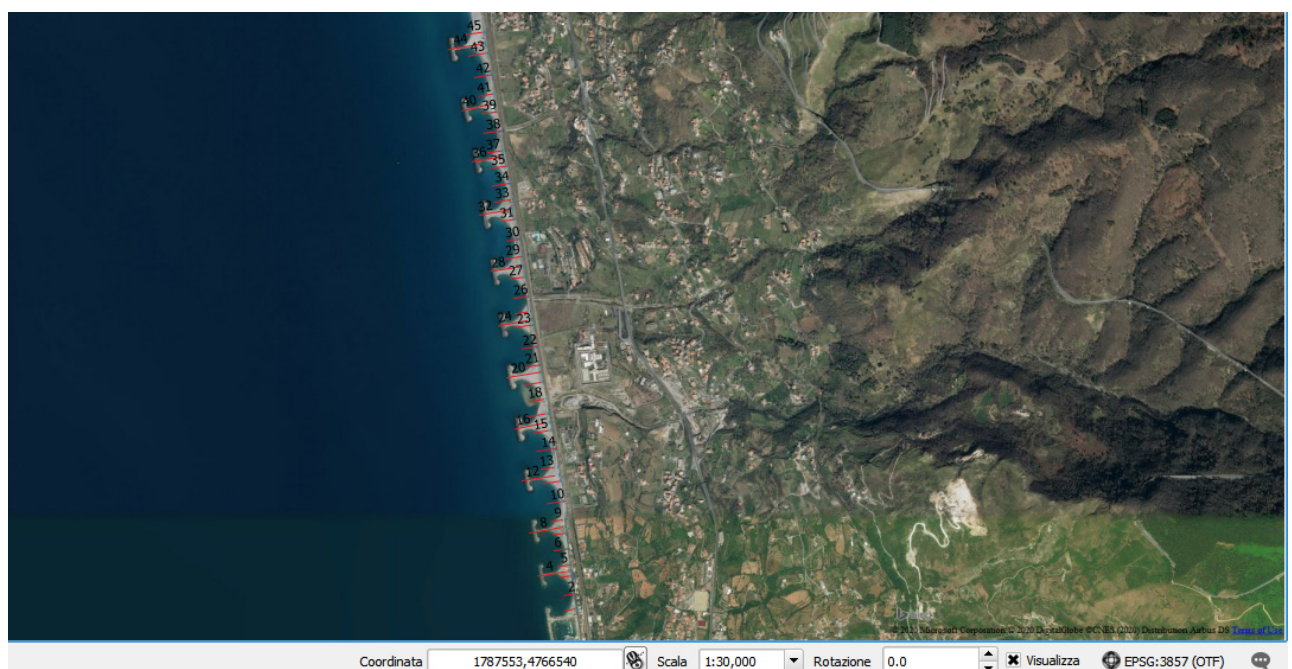

Figure 4: View from QGIS of San Lucido. Red = Transepts.

\section{METHODOLOGY}

The analysis of the shoreline changes was carried out through the comparison of various cartography data, which consists of historical shorelines of 1954, 1998, 2000 and 2008 taken from the Open Data section of the Calabrian Geoportal, orthophotos of 1989, 1996, 2006 and 2012 taken from the Open Data section of the Italian Geoportal, and satellite imagery from 2015 to today provided by Google Earth.

The analysis was divided into four phases as follows. The first phase concerned the manual digitization of each missing shoreline, using QGIS for each orthophotos and using 
the spatial analysis tools of Google Earth Pro for each satellite imagery. The second phase concerned the evaluation of the beach width for each transept. Finally, the last phase concerned the determination of shoreline rates of change using end point rate (EPR) and net shoreline movement (NSM) statistics.

About the first phase, the digitalization of the missing shorelines was carried out on a scale of 1:1000 on QGIS and on a higher scale on Google Earth Pro. Therefore, the shoreline position has precision of the order of the meter and the shoreline changes have been approximated to the meter. This accuracy is in agreement with the aims of the paper, which concern the evaluate of the erosion and advancement trends, and not their precise quantification. Also, due to the varying oceanographic conditions among the different cartographies, the reference line chosen was the wet/dry line [37]. Furthermore, in the study area the tidal excursion is of the order of tens of centimeters [49] so the effects on the variation of the shoreline position are negligible.

Regarding the second phase, over 700 transepts were traced, with an average spacing of the order of a hundred meters and reducing it in the presence of coastal structures. Also, the related baselines were identified for each transept. These lines identify the upper limit of the beach and correspond to promenades, dunes and structures. The QGIS field calculator was used to automate the procedure. For this purpose, the shortest line function was used, which allows to calculate the minimum distance between a point and a straight line. In this case, the straight line is each baseline. Before this, it was necessary to insert a point at the intersection between each transept and the various shorelines, using the line intersection tool.

About the third phase, the NSM and EPR between any two successive shorelines have been calculated. The recent evolutionary trend of each transept was also assessed, comparing the two most recent shorelines in order to identify eroded, advancing and stable transepts. Also, for the case studies the NSMs were calculated between 1954 and the other lines, between 1989 and the other lines and, finally, between the most recent available shoreline and the others.

Regarding the last phase, the analysis above mentioned allowed to evaluate an index that describes the evolutionary trend of the shoreline. This index is based on Barbaro's methodology [28] and the average shoreline variation rate, $v$ expressed in $\mathrm{m} /$ year, was classified following a subdivision into 5 classes: one for the advancement $(v>0.5)$, one for the stability $(-0.5 \leq v \leq 0.5)$, one for erosion $(-1 \leq v<-0.5)$, one for intense erosion $(-2 \leq v<-1)$, and one for severe erosion $(v<-2)$. To estimate this rate, a quick methodology was developed to estimate the weighted average rate for each location examined, where the weight is given by the influence areas of each transept.

Furthermore, the evaluation of the evolutionary trend of the shoreline was carried out for different time intervals: the two most recent available shorelines; a short-term evolutionary trend, with reference to the shorelines available in the last 5 years; a medium-term evolutionary trend, with reference to the shorelines available in the last 20 years; a longterm evolutionary trend, with reference to the shorelines available in the last 30 years; a very long-term evolutionary trend, with reference to the shorelines available in the past 70 years.

\section{RESULTS AND DISCUSSION}

Table 1 shows a summary of the evolutionary trend in erosion, progress and stable for the whole of Calabria and for the three case studies. The evolutionary trend was estimated taking into account the two most recent shorelines available for each transept. Tables $2-4$ show the evolutionary trend, for different time intervals, of the three case studies. 
Table 1: Evolutionary trend taking into account the two most recent shorelines available.

\begin{tabular}{|l|c|c|c|c|c|c|}
\hline \multirow{2}{*}{ Site } & \multicolumn{6}{|c|}{ Evolutionary trend } \\
\cline { 2 - 7 } & Transepts & Advancement & Stability & Erosion & $\begin{array}{c}\text { Intense } \\
\text { erosion }\end{array}$ & $\begin{array}{c}\text { Severe } \\
\text { erosion }\end{array}$ \\
\hline Calabria & 710 & 281 & 157 & 64 & 52 & 156 \\
\hline Badolato & 10 & 8 & 0 & 0 & 0 & 2 \\
\hline Melito Porto Salvo & 15 & 4 & 1 & 1 & 1 & 8 \\
\hline San Lucido & 45 & 11 & 17 & 11 & 5 & 1 \\
\hline
\end{tabular}

Table 2: Evolutionary trend of Badolato.

\begin{tabular}{|l|c|c|c|c|c|c|}
\hline \multirow{2}{*}{ Time interval } & \multicolumn{6}{|c|}{ Evolutionary trend } \\
\cline { 2 - 7 } & $\begin{array}{c}\text { Rate } \\
\text { (m/year) }\end{array}$ & Advancement & Stability & Erosion & $\begin{array}{c}\text { Intense } \\
\text { erosion }\end{array}$ & $\begin{array}{c}\text { Severe } \\
\text { erosion }\end{array}$ \\
\hline Most recent & 3.71 & 8 & 0 & 0 & 0 & 2 \\
\hline Short-term & 3.71 & 8 & 1 & 1 & 0 & 0 \\
\hline Middle-term & 1.19 & 4 & 1 & 1 & 4 & 0 \\
\hline Long-term & -0.02 & 3 & 2 & 0 & 5 & 0 \\
\hline Very long-term & 0.71 & 6 & 4 & 0 & 0 & 0 \\
\hline
\end{tabular}

Table 3: Evolutionary trend of Melito Porto Salvo.

\begin{tabular}{|l|c|c|c|c|c|c|}
\hline \multirow{2}{*}{ Time interval } & \multicolumn{6}{|c|}{ Evolutionary trend } \\
\cline { 2 - 7 } & $\begin{array}{c}\text { Rate } \\
\text { (m/year) }\end{array}$ & Advancement & Stability & Erosion & $\begin{array}{c}\text { Intense } \\
\text { erosion }\end{array}$ & $\begin{array}{c}\text { Severe } \\
\text { erosion }\end{array}$ \\
\hline Most recent & -3.49 & 4 & 1 & 1 & 1 & 8 \\
\hline Short-term & -0.24 & 9 & 1 & 2 & 1 & 2 \\
\hline Middle-term & -2.31 & 0 & 5 & 0 & 4 & 6 \\
\hline Long-term & -0.98 & 0 & 2 & 8 & 5 & 0 \\
\hline Very long-term & -0.78 & 0 & 6 & 7 & 2 & 0 \\
\hline
\end{tabular}

Table 4: Evolutionary trend of San Lucido.

\begin{tabular}{|l|c|c|c|c|c|c|}
\hline \multirow{2}{*}{ Time interval } & \multicolumn{6}{|c|}{ Evolutionary trend } \\
\cline { 2 - 7 } & $\begin{array}{c}\text { Rate } \\
\text { (m/year) }\end{array}$ & Advancement & Stability & Erosion & $\begin{array}{c}\text { Intense } \\
\text { erosion }\end{array}$ & $\begin{array}{c}\text { Severe } \\
\text { erosion }\end{array}$ \\
\hline Most recent & -0.19 & 11 & 17 & 11 & 5 & 1 \\
\hline Short-term & -0.19 & 11 & 17 & 11 & 5 & 1 \\
\hline Middle-term & -0.27 & 5 & 20 & 14 & 6 & 0 \\
\hline Long-term & -0.18 & 12 & 24 & 6 & 2 & 1 \\
\hline Very long-term & -0.28 & 5 & 28 & 12 & 0 & 0 \\
\hline
\end{tabular}


Analyzing these tables, it is observed that, regarding the two most recent shorelines available, about $40 \%$ of the Calabrian examined transepts are in advancement, about $20 \%$ are stable and about $40 \%$ are in erosion, and more than half of which are in severe erosion. As regards Badolato, most of the transepts are currently in advancement and only two out of ten transepts are currently in severe erosion. However, also observing medium and long-term trends, about half of the transepts are stable or in advancement while the other half is in erosion. As for the rates, they are all positive, with high values in short-term and with more contained values in very long-term. The long-term rate is an exception and it is slightly negative. This condition is consistent with the impacts generated by the construction of a harbor in the early 2000s. Indeed, the construction of the harbor did not cause a loss of sediment but caused a different distribution, with a considerable advancement in the Southern transepts and an intense erosion in the Northern transepts [16]. In Melito Porto Salvo, on the other hand, there is a prevalence of erosive phenomena, which caused the loss of large beach areas. These phenomena are mainly concentrated in the middle-term and in the last two available data, with high erosion rate. This condition is mitigated only in the short-term, with a low erosion rate and with over $60 \%$ of the transepts in advancement. Finally, in San Lucido the trend is variable and, currently, $25 \%$ of the transepts are in advancement while the remaining part is equally divided between stability and erosion. With reference to the longterm, only 9 out of 45 transepts are in erosion, most of which is only in slight erosion. Regarding the rates, they are all negative but with low values, between 0.18 and $0.28 \mathrm{~m} /$ year This result is consistent with the construction of a series of mixed interventions (groins plus detached breakwaters) at the beginning of the 90s, which improved the evolutionary conditions of the shorelines in the long-term.

\section{CONCLUSIONS}

The paper shows how to use remote sensing and GIS to analyze coastal erosion. The analysis described in this paper was carried out in Calabria, a region of southern Italy of particular interest in the coastal erosion field due to its $750 \mathrm{~km}$ of coasts, many of which currently are anthropized and in erosion.

Over 50 Calabrian towns have been analyzed and, for each of them, the shoreline changes have been estimated, through the comparison of various cartographic data from different sources: Calabrian Geoportal, Italian Geoportal and Google Earth.

Also, an index that describes the evolutionary trend of the shoreline was defined. This index is based on Barbaro's methodology [36]. The average shoreline variation rate was classified following a subdivision into five classes (advancement, stability, erosion, intense erosion and severe erosion) and taking into account different time intervals: recent (the two most recent available shorelines); short-term (the last 5 years); medium-term (the last 20 years); long-term (the last 30 years); very long-term (the last 70 years).

The topics described in the paper is of particular relevance and interest in the field of planning and management of coastal areas and represent the basis for an index-based coastal risk assessment methodology. Furthermore, this methodology has several usefulness: it is of general validity, it is quickly applicable, it uses only free software and it allows to analyze cartographic data from different sources.

\section{REFERENCES}

[1] Komar, P.D., Coastal erosion: Underlying factors and human impacts. Shore and Beach, 68(1), pp. 3-16, 2000.

[2] Pranzini, E., Shore protection in Italy: From hard to soft engineering ... and back. Ocean and Coastal Management, 156(15), pp. 43-57, 2018. 
[3] Barbaro, G., Foti, G. \& Malara, G., Set-up due to random waves: Influence of the directional spectrum. Proceedings of the 30th International Conference on Ocean, Offshore and Artic Engineering OMAE, Rotterdam, The Netherlands, 6, pp. 789-797, 2011.

[4] Barbaro, G., Foti, G., Sicilia, C.L. \& Malara, G., A formula for the calculation of the longshore sediment transport including spectral effects. Journal of Coastal Research, 30, pp. 961-966, 2014.

[5] Tomasicchio, G.R., D’Alessandro, F., Barbaro, G., Musci, E. \& De Giosa, T.M., Longshore transport at shingle beaches: An independent verification of the general model. Coastal Engineering, 104, pp. 69-75, 2015.

[6] Barbaro, G., Foti, G., Mandaglio, G., Mandaglio, M. \& Sicilia, C.L., Estimate of sediment transport capacity in the basin of the Fiumara Annunziata (RC). Rendiconti Online Società Geologica Italiana, 21(1), pp. 696-697, 2012.

[7] Sicilia, C.L., Foti, G. \& Campolo, A., Protection and management of the Annunziata river mouth area (Italy). Journal of Air, Soil and Water Research, 6, pp. 107-113, 2013.

[8] Williams, A.T., Rangel-Buitrago, N., Pranzini, E. \& Anfuso, G., The management of coastal erosion. Ocean and Coastal Management, 156, pp. 4-20, 2018.

[9] Walling, D.E., Human impact on land: Ocean sediment transfer by the world's rivers. Geomorphology, 79(3-4), pp. 192-216, 2006.

[10] Yang, Z., Wang, T., Voisin, N. \& Copping, A., Estuarine response to river flow and sea-level rise under future climate change and human development. Estuarine, Coastal and Shelf Science, 156, pp. 19-30, 2015.

[11] Versaci, R., Minniti, F., Foti, G., Canale, C. \& Barillà, G.C., River anthropization, case studies in Reggio Calabria (Italy). WIT Transactions on Ecology and the Environment, vol. 217, WIT Press: Southampton and Boston, pp. 903-912, 2018.

[12] Zema, D.A., Bombino, G., Boix-Fayos, C., Tamburino, V., Zimbone, S.M. \& Fortugno, D., Evaluation and modeling of scouring and sedimentation around check dams in a Mediterranean torrent in Calabria, Italy. Journal of Soil and Water Conservation, 69(4), pp. 316-329, 2014.

[13] Fortugno, D. et al., Adjustments in channel morphology due to land-use changes and check dam installation in mountain torrents of Calabria (southern Italy). Earth Surface Processes and Landforms, 42(14), pp. 2469-2483, 2017.

[14] Barbaro, G., Saline Joniche: A predicted disaster. Disaster Advances, 6(7), pp. 1-3, 2013.

[15] Prumm, M. \& Iglesias, G., Impacts of port development on estuarine morphodynamics: Ribadeo (Spain). Ocean and Coastal Management, 130, pp. 58-72, 2016.

[16] Miduri, M., Foti, G. \& Puntorieri, P., Impact generated by Marina of Badolato (Italy) on adjacent coast. Proceeding of 13th International Congress on Coastal and Marine Sciences, Engineering, Management and Conservation MEDCOAST, Mellieha, Malta, 2, pp. 935-945, 2017.

[17] Fiori, E. et al., Analysis and hindcast simulations of an extreme rainfall event in the Mediterranean area: The Genoa 2011 case. Atmospheric Research, 138, pp. 13-29, 2014.

[18] Boudet, L., Sabatier, F. \& Radakovitch, O., Modelling of sediment transport pattern in the mouth of the Rhone delta: Role of storm and flood events. Estuarine, Coastal and Shelf Science, 198, pp. 568-582, 2017. 
[19] Barbaro, G. et al., Risk mapping of coastal flooding areas. Case studies: Scilla and Monasterace (Italy). International Journal of Safety and Security Engineering, 10(1), pp. 59-67, 2020.

[20] Barbaro, G., Petrucci, O., Canale, C., Foti, G., Mancuso, P. \& Puntorieri, P., Contemporaneity of floods and storms. A case study of metropolitan area of Reggio Calabria in southern Italy. Proceedings of New Metropolitan Perspectives (NMP), Reggio Calabria, Italy, 101, pp. 614-620, 2019.

[21] Canale, C. et al., Analysis of floods and storms: Concurrent conditions. Italian Journal of Engineering, Geology and Environment, 1, pp. 23-29, 2020.

[22] Jaranovic, B., Trindade, J., Ribeiro, J. \& Silva, A., Using a coastal storm hazard index to assess storm impacts in Lisbon. International Journal of Safety and Security Engineering, 7(2), pp. 221-233, 2017.

[23] Ramieri, E. et al., Methods for Assessing Coastal Vulnerability to Climate Change. ETC CCA Technical Paper, 1, pp. 1-93, 2011.

[24] Torresan, S., Critto, A., Rizzi, J. \& Marcomini, A., Assessment of coastal vulnerability to climate change hazards at the regional scale: The case study of the North Adriatic Sea. Natural Hazards and Earth System Sciences, 12(7), pp. 2347-2368, 2012.

[25] Narra, P., Coelho, C., Sancho, F. \& Palalane, J., CERA: An open-source tool for coastal erosion risk assessment. Ocean and Coastal Management, 142, pp. 1-14, 2017.

[26] Satta, A., Puddu, M., Venturini, S. \& Giupponi, C., Assessment of coastal risks to climate change related impacts at regional scale: The case of Mediterranean region. International Journal of Disaster Risk Reduction, 24, pp. 284-296, 2017.

[27] Foti, G. \& Sicilia, C.L., Analysis, evaluation and innovative methodologies to prevent coastal erosion. WIT Transactions on Ecology and the Environment, vol. 169, WIT Press: Southampton and Boston, pp. 219-230, 2013.

[28] Barbaro, G., Master plan of solutions to mitigate the risk of coastal erosion in Calabria (Italy): A case study. Ocean and Coastal Management, 132, pp. 24-35, 2016.

[29] Mavromatidi, A., Briche, E. \& Claeys, C., Mapping and analyzing socioenvironmental vulnerability to coastal hazards induced by climate change: An application to coastal Mediterranean cities in France. Cities, 72, pp. 189-200, 2018.

[30] Mucerino, L. et al., Coastal exposure assessment on Bonassola bay. Ocean and Coastal Management, 167, pp. 20-31, 2019.

[31] McLaughlin, S. \& Cooper, J.A.G., A multi-scale coastal vulnerability index: A tool for coastal managers? Environmental Hazards, 9(3), pp. 233-248, 2010.

[32] Viavattene, C., Jiménez, J.A., Ferreira, O., Priest, S., Owen, D. \& McCall, R., Finding coastal hotspots of risk at the regional scale: The Coastal Risk Assessment Framework. Coastal Engineering, 2017.

[33] Satta, A., Snoussi, M., Puddu, M., Flayou, L. \& Hoult, R., An index-based method to assess risks of climate-related hazards in coastal zones: The case of Tetouan. Estuarine, Coastal and Shelf Science, 175, pp. 93-105, 2016.

[34] Pantusa, D., D’Alessandro, F., Riefolo, L., Principato, F. \& Tomasicchio, G.R., Application of a coastal vulnerability index: A case study along the Apulian Coastline, Italy. Water, 10(9), 2018.

[35] Kantamaneni, K., Phillips, M., Thomas, T. \& Jenkins, R., Assessing coastal vulnerability: Development of a combined physical and economic index. Ocean and Coastal Management, 158, pp. 164-175, 2018.

[36] Anfuso, G. \& Del Pozo, J.Á.M., Assessment of coastal vulnerability through the use of GIS tools in South Sicily (Italy). Environmental Management, 43(3), pp. 533-545, 2009. 
[37] Boak, E.H. \& Turner, I.L., Shoreline definition and detection: A review. Journal of Coastal Research, 21(4), pp. 688-703, 2005.

[38] Maglione, P., Parente, C. \& Vallario, A., Coastline extraction using high resolution WorldView-2 satellite imagery. European Journal of Remote Sensing, 47(1), pp. 685699, 2014.

[39] Maiti, S. \& Bhattacharya, A.K., Shoreline change analysis and its application to prediction: A remote sensing and statistics based approach. Marine Geology, 257(14), pp. 11-23, 2009.

[40] Ayadi, K., Boutiba, M., Sabatier, F. \& Guettouche, M.S., Detection and analysis of historical variations in the shoreline, using digital aerial photos, satellite images, and topographic surveys DGPS: Case of the Bejaia bay (East Algeria). Arabian Journal of Geosciences, 9, pp. 1-18, 2015.

[41] Moussaid, J., Fora, A.A., Zourarah, B., Maanan, M. \& Maanan, M., Using automatic computation to analyze the rate of shoreline change on the Kenitra coast, Morocco. Ocean Engineering, 102, pp. 71-77, 2015.

[42] Barbaro, G., Fiamma, V., Barrile, V., Foti, G. \& Ielo, G., Analysis of the shoreline changes of Reggio Calabria (Italy). International Journal of Civil Engineering and Technology, 8(10), pp. 1777-1791, 2017.

[43] Barbaro, G., Bombino, G., Foti, G., Borrello, M.M. \& Puntorieri, P., Shoreline evolution near river mouth: Case study of Petrace River (Calabria, Italy). Regional Studies in Marine Science, 29, 100619, 2019.

[44] Foti, G. et al., Shoreline changes near river mouth: Case study of Sant'Agata River (Reggio Calabria, Italy). European Journal of Remote Sensing, 52(4), pp. 102-112, 2019.

[45] Mills, J.P., Buckley, S.J., Mitchell, H.L., Clarke, P.J. \& Edwards, J., A geomatics data integration technique for coastal change monitoring. Earth Surface Processes and Landforms, 30(6), pp. 651-664, 2005.

[46] Alesheikh, A.A., Ghorbanali, A. \& Nouri, N., Coastline change detection using remote sensing. International Journal of Environmental Science and Technology, 4(1), pp. 61-66, 2007.

[47] Natesan, U., Parthasarathy, A., Vishnunath, R., Kumar, G.E.J. \& Ferrer, V.A., Monitoring long-term shoreline changes along Tamil Nadu, India using geospatial techniques. Aquatic Procedia, 4, pp. 325-332, 2015.

[48] Barbaro, G., Foti, G. \& Sicilia, C.L., Coastal erosion in the South of Italy. Disaster Advances, 7, pp. 37-42, 2014.

[49] Sannino, G., Carillo, A., Pisacane, G. \& Naranjo, C., On the relevance of tidal forcing in modeling the Mediterranean thermohailine circulation. Progress in Oceanography, 134, pp. 304-329, 2015. 